\section{Suspected cases of pulmonary tuberculosis referred from port of entry into Great Britain, 1980-3}

Most people arriving in Great Britain from the Third World do so at Heathrow Airport, London. All potential immigrants and a proportion of visitors are referred to the health control unit, where a general medical examination is carried out. In many cases a miniature chest radiograph is taken; if pulmonary tuberculosis is suspected the subjects are referred for inpatient assessment. ${ }^{1}$ About $70 \%$ of these patients are admitted to the Lister Unit, Northwick Park Hospital, Middlesex.

\section{Patients, methods, and results}

During January 1980 to January 1983 inclusive 203 patients were referred. Ages ranged from 18 to 99 years, with a bimodal distribution indicating predominantly young immigrants and older visitors. Most patients (91\%) originated from the Indian subcontinent; the remainder were from Africa, Vietnam, Hong Kong, and Europe. Of the 203 patients, six were excluded because of incomplete data and eight were found to have conditions other than tuberculosis. Thus 189 patients form the basis of this report.

Inpatient assessment included physical examination, a routine full sized posteroanterior chest radiograph, and routine blood tests. Three sputum and three gastric washing specimens were examined by direct smear for acid fast bacilli and subsequently cultured for Mycobacterium tuberculosis.

Of the 189 patients, 28 were smear positive for acid fast bacilli in either sputum or gastric washings taken on admission. After six weeks' incubation 47 patients yielded a positive culture for $M$ tuberculosis, 15 of these being reported resistant in vitro to one or more antituberculous agents. Of the 47 patients with positive cultures, 22 had been smear negative on presentation. Three patients who were smear positive (all specimens from gastric washings) failed to produce positive cultures.

Radiological reporting on chest radiographs obtained on admission. Figures are numbers $(\%)$ of reports $\left(n=184^{\star}\right)$

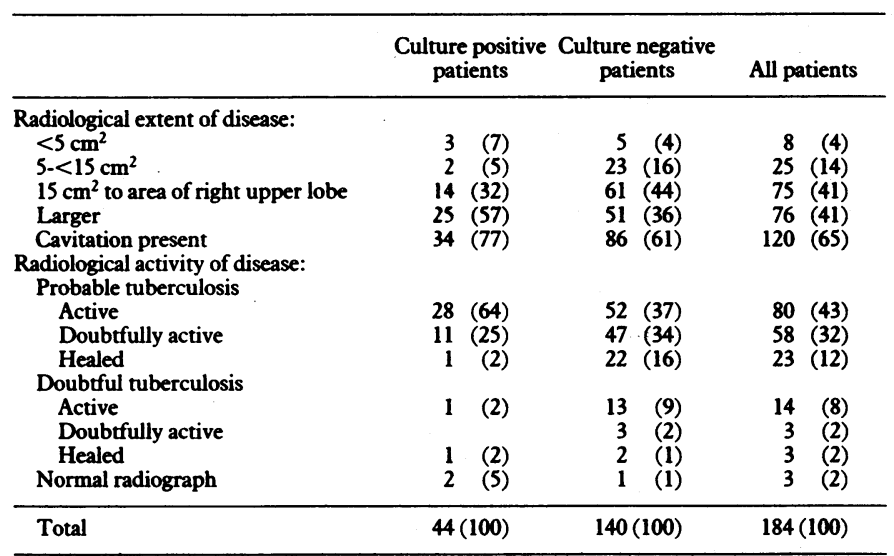

*Chest films were unobtainable in three patients who yielded positive cultures and two who yielded negative cultures.

Radiological reports were obtained for 184 patients, most of whom had extensive lesions (table). A report of "probable active tuberculosis" by the radiological assessor was significantly associated with a subsequent positive culture $(p=0.0035)$; increasing extent of disease also correlated with positive cultures $(p=0.032)$. These associations disappeared, however, when radiographs of patients who were smear positive were excluded.

\section{Comment}

Our patients represent $70 \%$ of the immigrants suspected of having tuberculosis who were referred from Heathrow Airport during the study period. A further quarter of immigrants suspected of having tuberculosis were referred to St John's Hospital, Hillingdon: four yielded cultures that were positive for tubercle bacilli (although records were not available for four months of the study). This gives 51 patients with positive cultures from 96638 people referred to the health control unit by the immigration authorities, or 52.8 cases $/ 100000$ referred. The annual notification rate of pulmonary tuberculosis among Indians resident in Britain in 1979 was 237/100000, and among Pakistanis and Bangladeshis it was 241/100000. ${ }^{2}$ Only $57 \%$ of these patients, however, yielded positive cultures, the numbers of patients with positive cultures being 135 and 137/100 000. Comparable numbers of patients with positive cultures for 1983 were 53 and $51 / 100000 .^{3}$ Thus over the study period as a whole fewer cases were being detected at Heathrow than arose spontaneously in the comparable ethnic groups resident in Britain-yet routine screening is no longer carried out among these groups. Our results suggest that the current screening of immigrants for tuberculosis is relatively ineffective.

About $80 \%$ of the patients referred from Heathrow were at high risk of bacteriological breakdown, and follow up of such patients is important. ${ }^{45}$ Regardless of whatever screening is carried out the names and addresses of new immigrants from the Third World should be forwarded to the relevant officer for environmental health.

We thank Dr G A Faux, principal medical officer, health control unit, and the staff at Heathrow Airport for kindly giving us access to their data. We also thank the staff of St John's Hospital, Uxbridge, for their cooperation. Miss Carole Berson, Mrs Denise Morton, and Mrs Eileen Anthony gave invaluable help in preparing and typing this manuscript.

1 Joint Tuberculosis Committee. Tuberculosis among immigrants in Britain. $\mathrm{Br} M e d f$ 1978; $1038-40$.

2 Medical Research Council Tuberculosis and Chest Diseases Unit. National survey of tuberculosis notification in England and Wales, 1978-9. Br Med $\mathcal{J}$ 1980;281:895-8.

3 Medical Research Council Tuberculosis and Chest Diseases Unit. National survey of notifications of tuberculosis in England and Wales in 1983. Br Med J 1985;291:658-61.

4 Hong Kong Chest Service, Madras Tuberculosis Research Centre, and British Medical Research Council. A study of the characteristics and course of sputum smear-negative pulmonary tuberculosis. Tubercle 1981;62:155-67.

5 Hong Kong Chest Service, Madras Tuberculosis Research Centre, and British Medical Research Council. A controlled trial of 2-month, 3-month and 12-month regimes of chemotherapy for sputum smear-negative pulmonary tuberculosis. Am Reo Respir Dis 1984;130:23-8.

(Accepted 23 October 1985)

Lister Unit, Northwick Park Hospital, Harrow, Middlesex HA1 3UJ

ANDREW C MARKEY, MB, MRCP, senior house officer

SUSAN M FORSTER, MB, MRCP, senior house officer

R MITCHELL, FRCR, consultant radiologist

ELLIOT LARSON, FRCP, consultant physician

HILLAS SMITH, FRCP, consultant physician

Clinical Research Centre, Harrow, Middlesex HA1 3UJ

C J DORÉ, BSC, medical statistician

Correspondence to: Dr A C Markey, Department of Medicine, Guy's Hospital, London SE1 9RT.

\section{Sensitivity to insect stings in patients taking anti-inflammatory drugs}

Bee stings are known to cause various reactions in different patients as well as on different occasions in the same patient. Anaphylactic reactions have been described in people who had previously developed no reaction to bee stings, and apparent spontaneous cure of their sensitivity has been reported. 'We report two cases of sensitivity to bee stings occurring while patients were taking anti-inflammatory drugs.

\section{Case reports}

Case 1-A 66 year old beekeeper had developed apparent immunity to bee stings over six years. She was prescribed diclofenac $50 \mathrm{mg}$ three times daily for severe bilateral hip osteoarthrosis, not taking other drugs and never having taken steroids. Some months after starting the anti-inflammatory treatment, however, she was stung on the wrists while attending her beehives and within 15 minutes developed an alarming reaction with palpitations, a rash over the trunk and limbs, and swelling of the mouth and tongue causing dyspnoea. This settled spontaneously within a few hours. The following day she did not take any drugs but again sustained several bee stings, and although a similar reaction developed, it was much milder. The next day- 48 hours after her last dose of the diclofenac-further bee stings had no effect. She took no more anti-inflammatory drugs and had no further reactions.

Case 2-The 48 year old wife of a beekeeper had previously had only local reactions to wasp stings. She had taken ibuprofen for osteoarthritis of the spine for five months before she was stung by a wasp. Within two minutes generalised swelling, red itchy rash, palpitations, and shortness of breath developed, with a sense of impending doom. Treatment in hospital for 24 hours included parenteral adrenaline, antihistamine, and hydrocortisone. Another wasp stung her two days later, after she had stopped taking ibuprofen, and a less severe reaction developed, possibly helped by speedier transfer to hospital. Further anti- 
inflammatory drugs were taken and she began a course of desensitisation to wasp venom.

\section{Comment}

Immunity to bee stings is well known among beekeepers, indeed it appears that people get temporary relief from the pain of arthritis if they sustain several bee stings. Allergy to insect stings is a local or system type immediate hypersensitivity reaction mediated by IgE. The effect of allergy to anti-inflammatory drugs may not be the same in all subjects, as has been shown in asthmatic patients sensitive to aspirin. ${ }^{2}$ Treatment with antiinflammatory drugs is widespread and may be overlooked in victims of bee stings as a possible complicating factor.

We have found no previous report saying that diclofenac, ibuprofen, or other non-steroidal anti-inflammatory drugs can reversibly modify the immune response. Though changes in specific tests have been shown in animal and in vitro experiments, ${ }^{3-5}$ no noticeable general immunosupression has been reported in a clinical situation.

We think that all beekeepers should be warned of this possible hazard if prescribed non-steroidal anti-inflammatory drugs.

1 Ewan PW. Allergy to insect stings: a review. $\mathcal{R} R$ Soc Med 1985;78:234-9.

2 Asad SL, Kemeny DM, Youlten LJF, Frankland AW, Lessof MH. Effect of aspirin in "aspirin sensitive" patients. Br Med f 1984;288:745-8.

3 Aleksandrowa GM, Roshkowa WN, Borissowa LN. Study comparing immunotrophic effects of diclofenac sodium, indomethacin and sodium salicylate. Farmakol Toksikol 1981;44:450-3.

4 Lang G, Phumb N, Kraus H. Infuence of diclofenac on PHA-bymphocyte: stimulation in RA patients and controls. Bethesda, Maryland: International League against Rheumatism, 1977:256. (Abstracts from XIV International congress of rheumatology.)

5 Wildfeuer A. Effect of anti-rheumatic drugs on the release of lysosomal enzymes from human leukocytes. $Z$ Rhewomatol 1984;43:23-6.

(Accepted 30 October 1985)

Department of Orthopaedic Surgery, East Birmingham Hospital, Birmingham B9 5ST

ANTHONY A BERNARD, FRCSED, registrar

JONATHAN B KERSLEY, FRCS, consultant orthopaedic surgeon

Correspondence to: $\mathrm{Mr}$ Kersley.

\section{Social class and age distribution in Reye's syndrome}

We carried out a study to see whether social class affects the age of onset in fatal cases of Reye's syndrome in Great Britain.

\section{Patients, methods, and results}

The age at death and the father's occupation (obtained from the death certificate) in all 72 officially recorded fatal cases of Reye's syndrome that occurred in the British Isles between August 1981 and April 1984 were obtained from the joint surveillance scheme for Reye's syndrome of the British Paediatric Association and the Communicable Disease Surveillance Centre. The fathers occupations were classified, blind to age, into six social groups $(1$, professional; 2 , intermediate; 3 , skilled non-manual; 4, skilled manual; 5, partly skilled; 6 , unskilled) using a modification of the Registrar General's scheme (table). Seven of the 72 were unclassifiable. There was a significant negative correlation (Spearman correlation coefficient $-0.412, t=-3.5889, p=0.0005$ ) between ranked socia class and ranked age at death in months. There was also a significant difference between the observed number of cases in each social class and the number expected from the distribution of social classes in the general population $\left(\chi^{2}=47 \cdot 72, \mathrm{p}<10^{-6}\right)$.

\section{Comment}

The joint surveillance scheme has attempted to register all cases of Reye's syndrome occurring in the British Isles since $1981 .^{1}$ Data from death certificates are included and therefore under-registration is probably less likely with fatal than with non-fatal cases. Underdiagnosis, however, could be a considerable problem with this rare condition, as could the inclusion of certain inborn errors of metabolism that are indistinguishable from Reye's syndrome unless detailed metabolic studies are carried out. ${ }^{2}$ Furthermore, no precise or universally agreed determinant of social class or social conditions exists, and classification is further limited when only self descriptions of fathers' occupations are available.

There are many possible differences between social groups, including geographical location, diet, exposure to environmental toxins, genetic constitution, and access to medical facilities. These could all affect the incidence, outcome, or diagnosis of Reye's syndrome, but why they should affect the age of onset is unknown. One possibility is that Reye's syndrome comprises at least two diseases, one of which is associated with social disadvantage and occurs early while the other is associated with socia advantage and occurs later in life. The observed excess of cases in socia groups 1 and 6 provides some support for this view (table).

Another possible explanation arises from the fact that diseases caused by common micro-organisms spread by the faecal-oral route or close personal contact show this pattern of age at onset. The age incidence of first contact with a common organism falls rapidly through childhood, in a manner analogous to half life decay. If improved social conditions cause the organism to circulate more slowly then the incidence of first contact falls more slowly and the mean age at onset rises.

Age at death of children with Reye's syndrome by social class

\begin{tabular}{|c|c|c|c|c|c|c|c|}
\hline & \multicolumn{7}{|c|}{ Social class } \\
\hline & 1 & 2 & 3 & 4 & 5 & 6 & All \\
\hline \multirow{2}{*}{$\begin{array}{l}\text { Age at death (months): } \\
\text { Mean age } \\
\text { Median age } \\
\text { Interquartile range } \\
\text { Age range } \\
\text { No }(\%) \text { of cases } \\
\% \text { Of people in general popula- } \\
\text { tion in each social classt }\end{array}$} & $\begin{array}{c}106 \\
118 \\
40-165 \\
27-180 \\
8(12 \cdot 3)\end{array}$ & $\begin{array}{c}55 \\
28 \\
16-85 \\
1-170 \\
17(26 \cdot 2)\end{array}$ & $\begin{array}{c}39 \\
16 \\
10-59 \\
5-112 \\
7(10 \cdot 8)\end{array}$ & $\begin{array}{c}55 \\
51 \\
5-77 \\
1-146 \\
13(20)\end{array}$ & $\begin{array}{c}28 \\
9 \\
6-45 \\
1-85 \\
7(10 \cdot 8)\end{array}$ & $\begin{array}{c}20 \\
6 \\
4-19 \\
0-95 \\
13(20)\end{array}$ & $\begin{array}{c}50 \\
25 \\
6-77 \\
0-180 \\
65(100) \star\end{array}$ \\
\hline & 6.6 & $25 \cdot 1$ & 10.1 & $39 \cdot 7$ & $14 \cdot 2$ & $4 \cdot 3$ & 100 \\
\hline
\end{tabular}

«Seven missing cases.

tSocial class of economically active or retired husbands of married couples aged 16-44 in private households with one or more dependent children, England and Wales, 1981 census, private households with one or more dependent children, England and Wales, 1981 census,

Reye's syndrome often occurs after viral infections of the respiratory tract, ${ }^{2}$ though many of these viruses, such as influenza $B$, cause disease throughout life and are not confined to the age group in which Reye's syndrome occurs. ${ }^{3}$ Viruses can, however, disturb the bacterial flora in the respiratory tract and lead to overgrowth of common Gram negative bacilli. Furthermore, although there is no evidence that viraemia or bacteraemia directly causes Reye's syndrome, the disease has a clinical picture of toxaemia, ${ }^{2}$ and animal models of the disease have been developed using bacterial toxins as causative agents. ${ }^{5}$ Thus one possible explanation for our findings is that in some cases Reye's syndrome occurs because a chance first encounter with common toxigenic bacteria after a viral infection leads to bacterial overgrowth and toxaemia before immunity has developed.

We thank the Reye's syndrome surveillance scheme of the British Paediatric Association and the Communicable Disease Surveillance Centre and the Office of Population Censuses and Surveys for supplying the primary data. We also thank Professor J A Davis, professor of paediatrics at the University of Cambridge, and Dr A P Mowat, consultant paediatrician, King's College Hospital, London, for comments.

1 Hall SM, Bellman MH. British Reye's syndrome surveillance scheme, methodology-results. In Pollack JD, ed. Reye's syndrome IV. Bryan, Ohio: National Reye's Syndrome Foundation, 1985:32-47.

2 Mowat AP. Reye's syndrome: 20 years on. Br Med f 1983;286:1999-2000.

3 Sullivan-Bolyai JZ, Corey L. Epidemiology of Reye's syndrome. Epidemiol Rev 1981;3:1-26.

4 Ramfrez-Ronda CH, Fuxench-Lopez Z, Nevarez M. Increased pharyngeal bacterial colonizatio during viral illness. Arch Intern Med 1981;141:1599-603.

5 Yoder MC, Egler JM, Yudkoff M, Chatten J, Douglas SD, Polin RA. Metabolic and mitochondria morphological changes that mimic Reye's syndrome after endotoxin administration to rats. Infect Imemen 1985;47:329-31.

(Accepred 15 November 1985)

Department of Pathology, Lancaster Moor Hospital, Lancaster LA1 3JR J A MORRIS, MRCPATH, consultant pathologist

Department of Sociology, University of Lancaster

D Z SHAPIRO, MA, lecturer

Correspondence to: Dr Morris. 